\title{
a importância da pesquisa para a formação e o Desenivolvimento AcadêMICO
}

Ellamy Alataremga de Araújo

\section{Introdução}

Inicialmente eu gostaria de agradecer à Comissão organizadora deste evento o convite para proferir esta palestra, o qual me proporcionou dois momentos extremamente importantes. O primeiro momento foi o de repensar a pesquisa e o ensino no campo da biblioteconomia, da documentação e da ciência da informação, resultando neste texto. $\mathrm{O}$ segundo momento é este que estou vivendo agora, pois estar com vocês, professores de biblioteconomia da região Sul, é algo muito importante para mim porque representa a possibilidade de conhecer outra realidade. Como professora da UFPB, conheço muito bem os problemas que os professores da região Nordeste têm vivenciado, e, assim como vocês, eles têm se reunido constantemente para discutir esses problemas. Estar aqui significa poder ampliar a minha compreensão sobre essa questão e, por isso, eu me sinto uma pessoa privilegiada. Mais uma vez, obrigada.

\section{A relação entre pesquisa e ensino}

O tema desta palestra se fundamenta na afirmação de que a pesquisa é importante tanto para a formação como para o desenvolvimento acadêmico - com a qual, acredito, todos nós concordamos. Na verdade, os profissionais de biblioteconomia e documentação têm manifestado seu reconhecimento sobre a importância da pesquisa em diversas oportunidades. O início formal das discussões em âmbito nacional data de 1950, quando a professora Maria José Thereza de Amorim apresentou o trabalho Encorajemos as investigações em biblioteconomia e documentação (2) no II Congresso Brasileiro de Biblioteconomia e Documentação, realizado em Salvador, BA. Entretanto, a simples concordância em relação à importância da pesquisa para a área não encerra a discussão, ao contrário, provoca outras questões, como:

Qual a relação entre pesquisa e ensino?

Se a pesquisa é importante, por que um número tão reduzido de profissionais e professores se dedica a essa atividade?

Eu compreendo como pesquisa "qualquer investigação metódica desenvolvida para fornecer informações que possam solucionar um 
problema". Na verdade, a pesquisa é a expressão da necessidade humana de compreender o mundo, a fim de viver melhor.

A pesquisa é um tipo de estudo que se fundamenta em determinados caminhos (métodos e técnicas), objetivando apresentar soluções para problemas que envolvem as pessoas em suas atividades cotidianas. Em nosso caso, esses problemas se relacionam ao ensino, seja em seu aspecto de forma como de conteúdo.

Se considerarmos o ensino como atividade de construção de conhecimento, como atividade que "ensina a aprender", veremos que o campo no qual se inicia é a pesquisa. Assim, o ensino se fundamenta na pesquisa para realizar a grande tarefa de ensinar a pensar. Através dessa ação educacional, o professor se transforma em construtor de conhecimentos e não apenas em transmissor deles. A questão da transmissão do conhecimento é uma questão fundamental para a sociedade, como sempre foi, mas considero que essa atividade não precisa de professor, nem de escola e muito menos de universidade. Atualmente, a transmissão de conhecimento está sendo feita, cada vez mais, pela "instrumentação eletrônica”, através de cursos à distância e de treinamentos. Assim, penso que a essência do ensino não seja a transmissão de conhecimentos, mas a sua construção através da pesquisa. Como coloca Pedro Demo (3), a didática fundamental será a do "aprender a aprender", sendo fundamentada na pesquisa como princípio científico educativo. Dentro desse contexto, a aula deixa de ser uma atividade de reprodução, e o professor deixa de ser uma figura que repassa um conhecimento de segunda mão para alunos de segunda mão, numa universidade de segunda mão.

A atividade didática se define como atividade de ensino/aprendizagem e faz parte do lema "aprender a aprender" mas, da maneira como se acostumou a fazê-la, ela é instrumental, pois apenas apresenta e ensina como determinadas técnicas e instrumentos são utilizados. Este tipo de ensino não ensina a pensar sobre os problemas e, a partir daí, empregar não apenas soluções já existentes, mas também criar novas soluções para velhos problemas. Assim, tanto professor como aluno aprendem a aprender, ou seja, aprendem a desenvolver a capacidade essencial de dar respostas inteligentes a partir de um contexto específico e de um determinado problema. Dessa forma, o ensino deixa de ser apenas repasse de conhecimentos e/ou resposta aos apelos do mercado de trabalho, da competitividade e da qualidade, tornando-se atividade que gera cidadãos com capacidade crítica e criativa. Através dessa visão do processo de ensino, orientado pela pesquisa, o professor passa, em conjunto com seus alunos, a ser criador de conhecimentos. Afinal, um professor que pesquisa se torna um indivíduo interessado em tudo e em todas as colocações e, principalmente, ele se torna um indivíduo interessante para os alunos, pois sempre tem uma indagação e uma possível resposta.

Creio que se os professores conseguissem ocupar esse espaço de construção do conhecimento se tornariam elementos indispensáveis ao desenvolvimento, pois seriam 
reconhecidos pela sociedade como responsáveis pela produção do futuro.

Essa visão da relação entre pesquisa e ensino possibilita a desmitificação da pesquisa como algo a ser feito apenas pelos cursos de pósgraduação. Outro aspecto importante é que, através dessa visão, tanto a pesquisa como o ensino são considerados como momentos complementares de um mesmo processo - o processo de construção do conhecimento.

Ao reconhecer a importância da pesquisa para o ensino, é preciso reconhecer também que existem dificuldades para a implementação dessa atividade, ponto que deve ser discutido.

\section{A problemática da realização de pesquisa pelos professores de biblioteconomia e documentação no Brasil}

Um segundo ponto para discussão se relaciona ao fato de a pesquisa ser feita por um número reduzido de profissionais e professores. Por que? Porque existem dificuldades para a implementação de atividades de pesquisa de forma regular e eficiente, pois, na verdade, apesar de sua reconhecida importância, a pesquisa enfrenta várias dificuldades para a sua realização.

No campo da biblioteconomia brasileira, as dificuldades para a realização de pesquisas pelos professores podem ser classificadas em institucionais e individuais, como seguem:

\section{Dificuldades institucionais:}

ausência de verbas específicas para pesquisa na maioria das universidades brasileiras;

carga horária destinada quase exclusivamente ao ensino (fato denominado "aulismo"), gerando carência de tempo para a pesquisa;

acervos deficientes para apoiar a atividade de pesquisa;

reduzida cooperação interinstitucional na área de biblioteconomia, gerando baixo aproveitamento de recursos humanos capacitados.

Dificuldades individuais:

dificuldades em relação a idiomas estrangeiros;

reduzido contato profissional entre os professores da área (comunicação informal). Apesar das várias tentativas feitas pela $\mathrm{ABEBD}$, considero que essa dificuldade ainda existe;

conhecimento restrito sobre metodologias de pesquisa por parte dos professores.

\section{Conclusões}

A apresentação dessas dificuldades não objetiva causar desânimo entre os colegas, mas propiciar uma discussão que possa gerar soluções. Essas soluções, então, originam-se na discussão e na implementação de ações concretas no sentido de apoiar e difundir a prática da pesquisa entre os professores da área, fazendo

Inf.\&Inf., Londrina, v.1, n.1, p.18-21, jan./jun. 1996 
com que a pesquisa seja tão rotineira para os professores de biblioteconomia e documentação como as atividades de ensino.

Concluo esta palestra, esperando ter apresentado pontos interessantes para debate. Obrigada pela atenção.

(1) Professora do Curso de Biblioteconomia e Documentação da Universidade Federal da Paraíba - UFPB; doutoranda em Ciência da Informação na Universidade de Brasília - UnB.

(2) BARRETO, Clara Maria Weber. A problemática da realização de pesquisa pelos professores de biblioteconomia. Brasília: Universidade de Brasília, 1981. Dissertação (Mestrado).

(3) DEMO, Pedro. Pesquisa como definição essencial da vida acadêmica. Barbaroi, Santa Cruz do Sul, n. 0, p. 27-43, mar. 1994. 